This item was submitted to Loughborough's Research Repository by the author.

Items in Figshare are protected by copyright, with all rights reserved, unless otherwise indicated.

\title{
Positive youth development through an outdoor physical activity programme: evidence from a four-year evaluation
}

PLEASE CITE THE PUBLISHED VERSION

http://dx.doi.org/10.1080/00131911.2011.648169

\section{PUBLISHER}

Taylor and Francis / @ Educational Review

\section{VERSION}

AM (Accepted Manuscript)

\section{PUBLISHER STATEMENT}

This work is made available according to the conditions of the Creative Commons Attribution-NonCommercialNoDerivatives 4.0 International (CC BY-NC-ND 4.0) licence. Full details of this licence are available at: https://creativecommons.org/licenses/by-nc-nd/4.0/

\section{LICENCE}

CC BY-NC-ND 4.0

\section{REPOSITORY RECORD}

Armour, Kathleen, and Rachel A. Sandford. 2019. "Positive Youth Development Through an Outdoor Physical Activity Programme: Evidence from a Four-year Evaluation". figshare. https://hdl.handle.net/2134/19791. 
Running Head: POSITIVE YOUTH DEVELOPMENT THROUGH PHYSICAL ACTIVITY

\title{
Positive Youth Development through an Outdoor Physical Activity Programme: Evidence
} from a Four-Year Evaluation

\begin{abstract}
In 2006, the authors undertook a comprehensive review of the literature on the role of physical activity/sport and physical education in promoting positive development for disaffected youth (Authors, a). This paper revisits the findings of the literature review in light of data from a fouryear evaluation of one corporate-sponsored physical activity intervention in the UK. Literature on the role of physical activity/sport in positive youth development (PYD) is summarised and updated from the original review. Impact data were collected on 600 pupils (310 boys and 285 girls) and showed that there were some positive benefits for the majority of participants and that those pupils who participated for longer showed more sustained improvements. It is argued, however, that physical activity setting are no panacea, and that complex understandings of learning and skill 'transfer' from such programmes are required if sponsors and designers are to maximise the potential of sport/physical activity for positive youth development.
\end{abstract}

Keywords: Physical activity/sport interventions; positive youth development; youth disaffection; learning, evaluation methods

\section{Positive Youth Development through a Physical Activity/Sport Programme: Evidence from a Four-Year Evaluation}

This paper builds upon an earlier publication in which the authors reviewed the literature on youth disaffection and physical activity/sport. The review highlighted an apparent disparity in beliefs held about the role of physical activity/sport to effect positive changes, and the weight of evidence (Authors, a). The authors also suggested there was a need for more long-term, credible 
monitoring and evaluation of physical activity/sport and physical education initiatives in order to better understand the contexts and processes that are most likely to lead to optimal impact for young people. In 2008, the authors also reported summary findings from two projects (one being the project reported in this paper) both of which focused on using structured physical activity/sport as a vehicle for re-engaging disaffected youth and promoting positive personal and social development (Authors, b). This paper adds to the previous publications by providing detailed data and analysis from a four-year evaluation of one of the projects and considering ways in which future programmes can facilitate sustained impact by reconsidering underpinning concepts of learning and skill 'transfer'. The paper, therefore, has two interlinked aims: to report the outcomes of the evaluation, and to consider the ways in which both the evaluation process and the outcomes can add to the wider literature base on PYD through physical activity/sport.

The paper is organised into six sections: (i) a summary and update of literature presented in the previous papers; (ii) an overview of the wider positive youth development literature (iii) an overview of the outdoor/adventurous activity programme; (iv) evaluation design, methods and data analysis strategies; (v) main findings reported and analysed in the context of the issues identified in the earlier review paper and the wider PYD literature; (vi) discussion and implications for the design and conduct of future physical activity interventions that are seeking to use physical activity/sport as a form of PYD.

Throughout this paper, 'physical activity/sport' is used as an umbrella term to denote a broad range of sport, physical activity and physical education programmes or initiatives located in schools and communities. Some of these programmes are centred on one specific sport, whereas others have a broader physical activity or outdoor education remit. Although they can differ in their precise focus, with some being more competitive than others, they share similar (largely untested) philosophies about the potential value for young people of engagement in the 
Running Head: POSITIVE YOUTH DEVELOPMENT THROUGH PHYSICAL ACTIVITY

core physicality of such activities. 'Positive youth development' is defined in more detail below but, in summary, Damon (2004) and Holt (2008) argue it is a vision of positive adolescent development in which youth are regarded as a resource to be developed rather than a problem to be solved.

\section{(i) Youth Disaffection and Physical Activity/Sport Initiatives}

Problems of youth disaffection, disengagement and anti-social behaviour continue to loom large in public and political debate in the UK and beyond (Smink, 2000; Goldson \& Muncie, 2006; Authors, a). There are enduring concerns about the involvement of (some) young people in unhealthy, antisocial or indeed criminal activity. Such concerns engender a sense of fear about the potential threat to social and moral order posed by the younger generation (Davies, 2005). It is also apparent, however, that the concept of disaffection is complex and that it is not always defined clearly (Authors, a; Bailey, 2008). Moreover, youth disaffection is itself a complex, multi-dimensional phenomenon, influenced by numerous factors and encompassing a range of behaviours, attitudes and experiences (Newburn, Shiner, Groben \& Young, 2005; Sandford et al., 2008a). As such, disaffection manifests itself in different ways such as disruptive or antisocial behaviour, a rejection of civic responsibilities, and disengagement from educational services/activities (DfES, 2005; Kendall \& Kinder, 2005). For a more extensive discussion of these issues see Authors (a) and Bailey (2008).

Although concerns regarding 'problematic' youth have been evident throughout history (Hughes \& Follett, 2006) the scale of the current problem has led to calls for 'action' to address the situation (Sandford, Duncombe \& Armour, 2008b). This has resulted in a raft of policies, programmes and initiatives, many of which use physical activity/sport as a re-engagement tool. There is evidence of a long-standing faith in the power of physical activity/sport activities to 
instil positive attitudes and facilitate pro-social development for young people (Theodoulides \& Armour, 2001; Bailey, Armour, Kirk, Jess, Pickup \& Sandford, 2009). Indeed, from 2000 in the UK, physical activity, physical education and sport featured prominently in government policies on youth disaffection (e.g. PESSCL, PESSYP, NOPES, Positive Futures ${ }^{1}$ ) as well as in other funded youth re-engagement initiatives (Sandford et al., 2008b). Even though the new Coalition Government (DCMS, 2010) has questioned the general approach taken by the previous government, they have endorsed even more strongly one aspect of it; a belief in the importance of competitive sport in children's lives.

There is evidence of a global resurgent interest in the potential value of physical activity/sport, as witnessed by initiatives such as the United Nations International Year of Sport and Physical Education in 2005 (Bailey, 2008) and the European Commission White Paper on Sport (2007). In the UK, the approach of the London 2012 Olympics has heightened interest and expectations. For example, an Olympic legacy is planned to ensure that physical activity/sport engages hard to reach young people by driving strategies that will 'help address young people's under-achievement and disaffection' (DCMS website). Most recently, the new government have stated that they want to use 'the unique inspirational power of the Games to help disadvantaged young people’ (DCMS, 2010 p.10).

Yet, despite an enduring faith in the power of physical activity/sport engagement to build 'character', facilitate young people’s positive development and contribute to a social inclusion agenda, the evidence base for such assertions is thin. At the same time, it should be recognised that the expectations on physical activity/sport settings are increasing, especially in the UK with the approach of the London 2012 Olympic Games. In particular, and as was

\footnotetext{
${ }^{1}$ The PESSCL (Physical Education School Sport Club Links) strategy was launched by the UK government in 2002 and saw significant funding (£459 million) invested in physical education and school sport. PESSYP (Physical Education Sport Strategy for Young People) was launched in 2008 and is intended to build on the PESSCL strategy, with a further investment of $£ 755$ million over three years. The NOPES (New Opportunities for $\mathrm{PE}$ and Sport) initiative also saw significant investment ( $£ 751$ million) in PE and sport, supported by lottery funding. Positive Futures is a national social inclusion project in the UK that uses various activities, including sport, to engage with socially marginalised young people.
} 
Running Head: POSITIVE YOUTH DEVELOPMENT THROUGH PHYSICAL ACTIVITY

pointed out in our earlier review (Authors, a) relatively little is known about the influence of contextual factors on the degree of positive impact on young people, and even less is known about the precise mechanisms through which impact occurs, or the degree to which positive changes (and which changes) are sustainable/transferable (e.g. Holt, Tink, Mandigo \& Fox, 2008; Bailey et al., 2009). The findings reported here make a contribution to knowledge on these mechanisms, processes and changes. It is also interesting to note that there is growing interest in the potential of Positive Youth Development (PYD) as a theoretical approach that can inform the design of more effective physical activity/sport interventions, and this is now discussed in some detail.

\section{(ii) Positive Youth Development (PYD)}

A PYD approach to re-engaging disaffected or disengaged youth is based on a very specific view of youth transitions (Holt, 2008). Whereas traditional views of youth development see adolescence as a period of inevitable difficulty or conflict (so-called storm and stress), a PYD approach takes a more optimistic stance. Derived primarily from developmental systems theory, PYD focuses on the talents, strengths and potentials of each individual young person (Granger, 2002; Lerner et al., 2005a; Holt, 2008). As such, it represents a strength-based conception of youth development rather than a deficit-reduction approach (Lerner et al., 2005b). For example, as Damon (2004) expresses it; a PYD perspective 'emphasizes the manifest potentialities rather than the supposed incapacities of young people' (p.15). Thus, PYD emphasises the 'plasticity' of human development, recognising that all young people have the potential for change. It has been argued by its proponents (Granger, 2002; Lerner et al, 2005b) that this philosophy foregrounds an understanding of youth development as being not only about preventing undesirable behaviours but, importantly, also about the promotion of desired outcomes 
Running Head: POSITIVE YOUTH DEVELOPMENT THROUGH PHYSICAL ACTIVITY

Holt (2008) argues that while the term 'positive youth development' is used widely in the field of adolescent development, the relative infancy of the field means that there is ambiguity in definitions. There is, however, some agreement about the central PYD processes. For example, there is a focus within PYD theory on viewing young people as being in possession of developmental resources, often referred to as strengths or assets. These assets can contribute to a young person's current and future wellbeing by maximising their potential to achieve and their resiliency to withstand difficult circumstances (Granger, 2002; Damon, 2004). There are similarities here with the notion of building social capital (e.g. Colley, 2003; Winter, 2003; Bailey, 2005) and it is clear that both approaches share conceptual roots in the wider sociological theories of authors such as Bourdieu (1997) and Putnam (2000). Interestingly, however, the PYD approach emphasises the importance of context in relation to developing resources, assets or capital (Damon, 2005; Lerner et al., 2008). Thus, PYD highlights the significance of the relationship between young people and their communities; or, as Granger (2002) puts it, ‘the transactions among developing youth and their ecologies’ (p.149). This, in itself, highlights an important aspect of the PYD approach; namely the reciprocal nature of the relationships between young people and their communities. On the one hand, PYD seeks to create supportive communities for young people, but there is also an underlying aim of encouraging individuals to contribute in positive ways to community welfare. As Whitlock (2004) has noted, PYD needs to be viewed more as a community strategy than a programme strategy. Similarly, Jones (2005) has noted that PYD focuses on 'those resources and assets in a community that offer young people positive choices, experiences, and support' (p. 1) and has, again, argued that a key role of the approach is to facilitate supportive relationships between young people and adults. Certainly, the quality of personal relationships is viewed as all important within PYD theory; as Lerner et al., (2008) note, 'in all settings, people are the most 
important developmental asset associated with PYD’ (p.11). The findings of the evaluation reported in this paper reinforce this point.

The PYD approach resonates strongly with contemporary physical activity/sport and youth re-engagement literature, particularly in its emphasis on the centrality of social processes, the need to develop positive, sustained relationships between young people and key adults (e.g. teachers, activity leaders and mentors), and the importance of providing opportunities for young people to be served by and to serve others (Hellison, 1995; Donnelly \& Coakley, 2002;

Sandford et al., 2008b). Indeed, the core principles of the PYD approach (the 'five Cs': Competence, Confidence, Connection, Character and Caring/Compassion) reflect these views. It is perhaps unsurprising, therefore, that researchers working in the fields of sport, physical activity and physical education are drawing upon PYD theory in their research (e.g. FraserThomas, Côté \& Deakin, 2005; Holt et al., 2008). There would certainly appear to be much potential for the theory to inform the development of future programmes, policies and initiatives. In the case of the intervention at the centre of this paper, key PYD principles underpinned its design and the ways in which relationships between the funders and five partner schools were developed.

\section{(iii) Intervention Overview}

The project at the heart of this research was developed from a partnership between a global corporation - HSBC - through its social responsibility section ${ }^{2}$, the Outward Bound Trust ${ }^{3}$ and five secondary schools (pupils aged 11-16) local to the HSBC Head Office in the Docklands area of London. The intervention ran for five years from September 2003 to August 2008, and

\footnotetext{
2 The project was funded by HSBC in the Community, which is a sub-group of HSBC's corporate social responsibility arm that has responsibilityfor promoting positive relationships with the local community. ${ }^{3}$ The Outward Bound Trust is an educational charity with a long history of providing outdoor, educational experiences to both young people and adults (see www.theoutwardboundtrust.org.uk).
} 
the sponsors (HSBC) also funded an independent evaluation project to run alongside the initiative and to report regularly on progress/impact to a steering group. The intervention was developed by HSBC following its move to new headquarters in the financial district of London, and was intended to: make a positive contribution to the local community (which is characterised by high levels of social deprivation); aid the personal, social and educational development of the participants; and encourage/re-engage pupils in education both immediately and in their futures. In order to fulfil these aims, the intervention sponsor worked with Outward Bound to develop a programme using outdoor/adventurous activities as a vehicle for promoting young people’s personal, social and educational development.

The format of the intervention changed slightly over the five year period; however the overall framework remained constant. For the first three project years (2003-06), 30 young people from year 9 (age 13-14) in each of the five partner schools (total 150 per year) were selected to take part in an organised programme of activities that spanned a whole school year (September to August). Pupils were selected by their teachers for a range of reasons, within the overall guidance from the project sponsors to select pupils who were perceived to be disaffected or disengaged in some way, and who could 'benefit' from project participation. Some supporting activities were to be school-led and based (although these proved to be problematic to organise), while a one week residential outdoor education experience was the programme highlight. The activity sessions were designed by Outward Bound to provide individual and group challenges and to develop skills such as team building, communication, and responsibility.

A key project feature was that pupils who were perceived by teachers, mentors and instructors to have 'gained the most' from the initial experience were given the opportunity to progress further. So, while 150 pupils attended an initial week-long residential at an Outward Bound centre, only 50 (i.e. 10 from each school) were selected to attend a weekend residential 
event later in the year. Moreover, at the end of the project year, a smaller number of pupils (2 from each school) were selected to undertake a three-week Classic Course ${ }^{4}$. For the last two cohorts (2006-08) the same number of pupils took part each year (150) but the order of activities was changed the larger number of pupils being offered the weekend programme first. Throughout all five years of the project, employees from HSBC's head office were involved as volunteer 'mentors'. The mentors were trained by youth workers from one of the project schools to work with schools and pupils both within the activity sessions (which were led by Outward Bound instructors) and, in theory, in follow-up activities within the schools.

During the five year lifetime of the intervention, approximately 750 young people participated, supported by 7 regular members of school staff (with additional help for residential sessions) and 57 different HSBC mentors ( 9 of these being involved with more than one group of pupils). Activity sessions took place at venues in and around London as well as at two national Outward Bound centres. At the end of each year of the programme, there was an awards/presentation evening for all participants at HSBC's Head Office in London. Although the evaluation was funded for five years, data were collected on four cohorts (hereafter referred to as cohorts 1-4) with the final year of the research funding dedicated to following up earlier cohorts and attempting to complete the data sets.

The central evaluation strategy was to record individual pupil progress from their personal baseline profiles at regular intervals. As the programme progressed, and greater numbers of pupils were involved, schools found it increasingly burdensome to return the updated evaluation data. Nonetheless, by developing strong relationships with the participating schools, including joining regular project steering group meetings at HSBC, the researchers were able to collect data on approximately 500 young people, 7 members of school staff

\footnotetext{
${ }^{4}$ The Classic Course is a flagship program for the Outward Bound Trust, and is for young people between the ages of 14 and 24 years. It runs over 21 days, and involves a packed schedule of adventure/challenge activities. Over the duration of the course, participants are encouraged to take increasing responsibility for themselves and to develop their communication and organisational skills.
} 
Running Head: POSITIVE YOUTH DEVELOPMENT THROUGH PHYSICAL ACTIVITY

(teachers, youth workers and learning mentors), 51 HSBC mentors and the lead contacts for both HSBC in the Community and the Outward Bound Trust.

\section{(iv) Evaluation Design, Methods and Data Analysis}

The complex structure of the HSBC/Outward Bound (HSBC/OB) initiative, the composite and dynamic social contexts in which it was located, and the broad scope of its aims, presented some significant challenges for the evaluators. The task was to design a plausible evaluation strategy that would allow project impact (the core focus of the evaluation) to be ascertained over time. Granger (1998) has highlighted the challenges faced in establishing causality, i.e. determining that any perceived impact on participants is a direct result of project activities. Moreover, Crabbe et al., (2006) point out that in the context of sport-based programmes, such attempts can be seen as 'a rather crass effort to bang square pegs into round holes' (p.7). Other authors have noted the over-reliance of researchers on anecdotal or retrospective accounts, and have questioned the reliability of these and other predominantly qualitative methods in determining clear project outcomes (e.g. MacCallum \& Beltman, 2002; Maxwell, 2004). While agreeing with some of these criticisms, the researchers were faced with the task of evaluating a programme that gave teachers and schools considerable flexibility. Schools were, for example, invited to select any pupils who they felt could, in some way, 'benefit' from participation. This necessitated an evaluation research design that could capture, as a baseline, the reasons teachers used to selected individual pupils and any supporting evidence they could provide. It is important to note that the lead teachers were consistent throughout the project, so they were able to select the pupils, provide the baseline data and the updates during and after project involvement. 
Running Head: POSITIVE YOUTH DEVELOPMENT THROUGH PHYSICAL ACTIVITY

The theoretical framework for the evaluation was developed using a theory of change approach (Fulbright-Anderson, Kubisch \& Connell, 2002; Kellogg Foundation, 2004) in order to understand how and why the programme was designed, by the sponsors, to 'work' (Weiss, 1995). This understanding was then used to design the overall data collection strategy. In stage one, a basic Logic Model (Kellogg Foundation, 2004) was developed for the initiative to ensure that researchers and key project participants had a shared understanding of the links between project activities, intended outcomes, and the assumptions underpinning them. Following this, a more detailed Theory of Change Logic Model (Kellogg Foundation, 2004) was created, that focussed on developing indicators of change to inform the methodological framework.

In order to assure the quality of the data, the evaluators sought, among other things, to: collate data from multiple sources, establish a point of reference with the inclusion of a comparison group and report contextual factors that could have had an influence on participants’ views. In addition, and following the approach taken in the evaluation of the Positive Futures programme, the decision was taken to recognise the individual nature of programme impact by seeking to determine the 'distance travelled' (Crabbe et al., 2006) by each individual pupil. Crabbe et al. point to the importance of designing flexible research tools that are appropriate for each project. For example, their evaluation pointed to 'the limitations of fixed, inflexible and exclusively quantitative assessments of project and programme performance' (p. 4). Moreover, as House (2005) argues, evaluation studies often have to be 'methodologically ecumenical' and causation is rarely direct or simple. In a comment that resonates strongly with the challenges found in this research, House reminds us that even where the same intervention is rolled out, 'there are different teachers at different sites who produce different results' (p.1071). In other words, the challenges faced by the researchers were far from unique. 
Running Head: POSITIVE YOUTH DEVELOPMENT THROUGH PHYSICAL ACTIVITY

The flexible design of the Outward Bound intervention necessitated the use of detailed, qualitative research methods. The sponsors were enthusiastic about this approach but needed reassurance about its credibility and, in this regard, the National Centre for Social Research framework for assessing the quality of qualitative research (Spencer, Ritchie, Lewis \& Dillon, 2003) was helpful. The framework offered a useful 'checklist' for the evaluators and the sponsors, leading to a shared understanding of the rationale behind the research activities and clarity in the research reports to sponsors through the use of a common language.

\section{Research Methods}

A substantial body of literature emphasises the need to draw directly upon the views of young people when attempting to understand their perspectives on programmes and initiatives in which they are involved (Flutter \& Rudduck, 2004; Halsey et al., 2006; Alderson, 2008). A research strategy was devised, therefore, in which data were collected from multiple sources including young people - to find out whether and how PYD outcomes could be a) identified and b) attributed to the project (Oliver \& Lalik, 2001; Harper, 2002). Specific methods used were:

- researcher fieldnotes - based on participant observation of project activities, for example at the residential events;

- focus group discussions with pupils (20) and mentors (8);

- individual interviews with mentors (19), school staff (9) and Outward Bound staff (5);

- $\quad$ semi-structured reflective journals for pupils (384) and mentors (20);

- $\quad$ open-ended surveys for pupils (340);

- mid-evaluation survey for mentors, school staff and lead contacts (24).

In addition, a process of pupil profiling was used to capture some of the complex ways in which pupils were selected by teachers as participants, and to record pupil progress in these 
areas, during and after project participation, as perceived by those same teachers (see also Authors, b, c). These data were supplemented by the data from the other research methods. At the start of each project year, lead teachers/staff at each school were asked to use relevant school-held data and/or their professional judgement to provide a brief profile of the current 'status' of each selected pupil (e.g. their attendance, behaviour, academic achievements or perceived levels of self-esteem/confidence). They were also asked to identify their reasons for individual pupil selection for the project, highlight the benefits that they expected to see for pupils as a result of their participation and indicate what evidence would be used to determine the nature/extent of project impact for each individual.

The pro-forma for the profile took the form of a semi-structured table, with columns identifying the key aspects of data collection (as outlined above) and space left for teachers to enter relevant information for each pupil. There were no restrictions on how the data should be entered, thus allowing teachers the flexibility to record any hard data (where relevant) to provide a subjective account of their own judgement and/or to cite the views of other members of staff (e.g. form tutors, class teachers etc.). In addition, data (relating to pupil 'status' only) were requested on a comparison group of 10 pupils from each school in order to provide some point of reference for the evaluation data. These pupils had the same range of characteristics as project group pupils and could equally have been selected for project involvement ${ }^{5}$. The same school staff were then asked to update the pupil profiles at intervals throughout the project and beyond; i.e. at $6,12,24$ and 36 months until the pupils reached the end of compulsory schooling (aged 16). Over three years, this resulted in a total of 410 individual participant profiles and 120 comparison group profiles.

\footnotetext{
${ }^{5}$ This was not an ideal method of creating a comparison group, given that the project group consisted of 30 pupils. However, it was found to be the only workable method given that a) each teacher had complete freedom to select project pupils based on their perception of who would 'benefit' from the project in some way and b) teachers simply did not have the time or motivation to identify or track an additional group of 30 pupils each year.
} 
In order to provide an indication of the degree of perceived impact, staff were also asked at the end of each profile update to note whether the progress of pupils (in both project and comparison groups) had been largely positive (P), unchanged (NC) or negative (N), using their baseline profile information as a benchmark. This process of pupil profiling was used for all pupils participating in the first three years of the HSBC/OB project. However, following the change in project structure at the end of the third year (and in response to comments from school staff regarding the pressures of providing increasing amounts of evaluation data) the evaluators decided to adopt a more focused case-study approach for pupil participants in year 4 of the project. This proved to be advantageous because the data from the first three years were very consistent, and the five detailed pupil cases studies from each school in year 4 provided important explanatory data. No comparison groups were used in year 4 of the research.

\section{Data Analysis}

Analysis of the data from the surveys took the form of descriptive statistics; for example, the frequency of a particular response or the percentage of the total data set that this represented. With regard to the pupil profile data, the update information was also summarised to show the number and percentage of pupils who had improved from, maintained, or dropped below their baseline profiles (as perceived by teachers). The data from these sources, plus that from interview transcripts, journal writing and researcher fieldnotes, were collated and then analysed using a staged grounded theory process similar to that described by Harry, Sturges and Klingner (2005). Thus, data were analysed by coding in stages (Glaser \& Strauss, 1967; Strauss \& Corbin, 1998) resulting in the generation and verification of core themes. The decision was taken, however, to adopt Charmaz's (2000) notion of constructivist grounded theory allowing for a more 'open-ended' approach to the analysis process to facilitate active coding and a strong focus on participants' thoughts, feelings and differing points of view. Furthermore, in each 6 
monthly report to funders, data from different sources were combined to generate holistic case studies and profiles of individual participants, small groups and schools; and these data were also used to update the intervention logic model.

In order to maintain participant anonymity throughout the research, the five project schools are referred to as School A, B, C, D and E. In addition, when individual participant comments are presented, the names shown are pseudonyms allocated by the research team. The findings are now reported in three sections: impact as recorded in the profile data; extended impact where participants became engaged in a range of additional positive activities as a result of the intervention; and data on the specific examples of personal development.

\section{Limitations}

We acknowledge the limitations of this research design. As was noted earlier, neither the project sponsors - nor the researchers - could control how participants were selected for the project by teachers (although guidance was provided by the sponsors). Given this major challenge, the researchers had to rely on the internal consistency of teacher reporting on the pupils’ baseline and update profiles, supplemented by hard data where available (for example in the case of poor school attendance or recorded behaviour 'incidents'). In addition, the researchers supplemented the pupil profile data with the collection of qualitative data from both pupils and all the adult participants throughout the evaluation. Furthermore, as was noted earlier, it was impossible to provide a control group given the wide range of reasons teachers used for pupil selection. Attempts were made instead to identify a comparison group in each school, although even this proved to be largely unworkable in practice due to the demands on teacher time. The compromise strategy of identifying a smaller comparison group $(n=10)$ was partially successful in 3 schools, although the data should be treated with much caution. 


\section{(v) Findings}

\section{Findings from the pupil profile data}

As noted above, individual pupil profiles were central to the research design in order to record the 'distance travelled' by each participant (Crabbe et al., 2006). The profiling process was used extensively throughout the first three years of the project, providing an overview of impact on pupils in Cohorts 1, 2 and 3. Moreover, this impact can be viewed both collectively and individually. In other words, while the individual profiles can be grouped together to give a broader view of project impact (see Table 1), it is also possible to identify individual paths to progress (or otherwise) for specific pupils (see Table 2).

[Insert Tables 1 and 2]

There are a number of points of interest to highlight from the collated data in Table 1. Firstly, the majority of pupils who participated in the HSBC/OB project showed positive improvements from their baseline profiles, and over 50\% of pupils maintained this progress to the point of leaving school at 16 years (36 months after initial project involvement). In addition, where data were available, project group pupils appeared to outperform a comparison group of matched individuals who did not participate in project activities (although it must be emphasised that the comparison group data received was often patchy and, as such, cannot be considered wholly robust).

The data also showed that those pupils who progressed to the later stages of the project showed greater improvements from baseline than those who experienced only the initial week, with many (63\% and 75\% for the weekend residential and Classic Course events respectively) maintaining these improvements to the point of leaving school. This finding was supported by feedback received from school staff in interviews, with one teacher noting that "It is becoming 
Running Head: POSITIVE YOUTH DEVELOPMENT THROUGH PHYSICAL ACTIVITY

clear that those students with regular follow up input are continuing to achieve the most”. Data collated (through both focus group discussions and written feedback) from pupils who attended the final Classic Course event also indicated the level of impact from this particular event; for example:

"I have enjoyed the Classic Course so much and I will remember it forever. I believe it will sculpt my future and my approach to my future” (Alexandra, Cohort 4).

Despite such positive findings, however, it should also be noted that there was a trend for the degree of positive improvement to decrease following the cessation of organised project activities (after 12 months for most pupils). Moreover, it is important to remember that at the point of leaving school, involvement in the HSBC/OB project had made no recorded impact on approximately one third of pupils. The data from school staff provided some explanation; with several teachers suggesting it was important that pupils were 'interested in' or 'buying into' the project for positive impact to be achieved. For example, one teacher noted:

"I know there are some pupils (in our school) who would benefit from some kind of programme, but this one (HSBC/OB) is not the right one for them. They just wouldn't get anything from it” (School D)

It may be, therefore, that one reason for little or no recorded impact on some pupils was that they were not selected carefully enough for this particular project. Indeed, a number of pupils identified this point; for example:

"I think that the people who didn't improve, when they went (to the Outward Bound centre) they couldn't do it, they like blocked it out. They had this attitude like 'I don't want to do this'. You've got to try something to get better.” (Finlay, Cohort 2) 
"I just think that there's two different kinds of people. One is where they say 'I'm going to take part in this course and I want to achieve something and do something and take it back', and another one says 'I'm just going to do the course and come back’”. (Imran, Cohort 2)

Certainly, pupils who find the physical activity/sport context difficult or alienating are unlikely to gain much from the HSBC/OB experience.

\section{Findings on extended impact}

In addition to showing a broad picture of positive impact, the updated pupil profile data revealed that a considerable number of project group pupils who showed positive improvements from baseline went on to become involved in other developmental activities within and outside school. These included Duke of Edinburgh awards, Youth Enterprise or business mentoring, or roles of responsibility such as Head Boy/Girl, prefects or student council membership. At the end of the project, each school was asked to indicate the approximate number of their project group pupils (Cohorts 1 to 4) who fell into each of these categories. The available data are summarised in the following tables (Tables 3 and $4^{6}$ ):

[Insert Tables 3 and 4]

These data show that many of the pupils who benefited from involvement in the HSBC/OB project went on to other achievements within and outside of school. For example, for School D over $40 \%$ of pupils in each HSBC/OB Cohort became involved in other activities or programmes with a personal development aspect. These data also corroborate interview data from teachers who reported the benefits of extension opportunities:

\footnotetext{
${ }^{6}$ It should be noted that, despite repeated requests from the evaluators, limited data were received from School A, and none at all from School B, in relation to these issues.
} 
"I can give you examples of pupils who have really grown as a result of taking part (in the project). A lot of our guys go on to become prefects and things within school, but the ones who progress most are those who go on to do other things when the project finishes.” (Teacher, School D)

"Every year students who are involved in HSBC go on to other things, they become part of the school council, they join Duke of Edinburgh, they join Young Enterprise, they are much more motivated, generally, to get involved in other things. These students do really well.” (Teacher, School C)

It is important to recognise, of course, that in some cases, project schools may have actively supported the positive development of individual project participants by appointing them to roles of responsibility or privilege, and this may be a partial explanation for the strength of the data. However, in order for this to happen, some positive progress would have been apparent. Certainly, from evidence such as this it can be concluded that some of the specific objectives of the HSBC/OB project were met, namely: encouraging and re-engaging pupils; and helping pupils to become role models within schools.

\section{Findings on the nature of personal positive development}

An analysis of both the profile and interview data (from pupils and teachers) generated from Cohorts 1 to 4 of the project provide some support for the literature outlined in sections one and two. An illustrative summary of the pupil data from focus group discussions and individual journals is shown in Table 5.

[Insert Table 5] 
Running Head: POSITIVE YOUTH DEVELOPMENT THROUGH PHYSICAL ACTIVITY

It is interesting to note that, when asked what they felt they had learnt or gained through participation in the HSBC/OB project, one of the benefits most commonly cited by pupils was an increased willingness to try activities; to challenge themselves rather than simply saying ' $I$ can't do it'. Indeed, several pupils related this directly to encouragement given by their Outward Bound instructors and HSBC mentors, and it was also the attribute most frequently mentioned as transferable from project activities to other aspects of their day-to-day lives. Two other skills mentioned frequently were teamwork skills and communication skills. Indeed, these skills were often connected, with several pupils suggesting that a greater ability to communicate came from the experience of working with other people in their team.

"We did a lot of difficult games (activities) and for them to be completed we needed many skills such as teamwork, communication, cooperation, participation, trust, determination, support, and perseverance” (John, Cohort 2)

"In the evening we did tunnelling and I found it fun...it was dark, ugly and dirty and we had to work together to find our way through. I learnt to listen to people, trust my team mates and to always give all of the members the courage they need, especially when they are scared" (Henrik, Year 2)

The following speech, written by one pupil at the end of a Classic Course event, also helps to illustrate the perceived significance of social interaction (and, within this, communication and teamwork skills) in pupils’ experiences of the HSBC/OB project.

"I will be talking about my experiences during the 3 week Classic Course. I am in Read group, and in my group are (list names). All 9 of them have been my family for 3 weeks. They are all very special and they mean so much to me. I love them and I will miss them. The experience that has been challenging for me was raft building, this was because I learnt that you should put people first and if you work as a team you can achieve anything, such as climbing the tallest mountain in England, which is 
Running Head: POSITIVE YOUTH DEVELOPMENT THROUGH PHYSICAL ACTIVITY

Scafell Pike. When we reached the top of the mountain I felt really proud of myself. I have learnt so many things, such as reading a map, learning how to navigate, cooking our own food, building a tent, how to make new friends, helping people and much more. I had to think, talk, laugh, cry, smile, be a leader and help people. This has been one of the best experiences, which I will never forget...I would like to thank my instructor Jimmy, he has guided us through hell and back (and) has been very inspirational” (Tarik, Cohort 2)

There were many similarities between the teacher and pupil data, with school staff also mentioning teamwork, communication, willingness to try new things and self-confidence as key skills developed through participation in the HSBC/OB project. The importance of social interaction and building relationships through the process of jointly undertaking activities was also highlighted.

"I think it comes down to relationships. Thinking back to that first cohort, we built really close working relationships with those young people, doing the activities with them, climbing rocks, gorge walking, jumping off jetties, you name it! We were working with them consistently (and) they would come to see us about different things even after the project had finished" (Teacher, School C)

"I think the context is really important, getting out there and facing the challenges of the environment, the weather, the landscape and so on... it means that they have to talk to each other, trust each other and, you know, work together to get things done and to achieve their goals. All good life lessons” (Teacher, school D)

Teachers also frequently cited the development of leadership skills; for example:

“Ali has shown outstanding progress. He was selected for the Classic Course. His communication, teamwork and especially leadership are outstanding” (Teacher, School D) 
Running Head: POSITIVE YOUTH DEVELOPMENT THROUGH PHYSICAL ACTIVITY

"Paul has gained lots of confidence and leadership qualities. He's in line to be a school prefect” (Teacher, School A)

Indeed, in many cases, the development of leadership ability was seen to encompass other core skills such as communication, teamwork skills, problem-solving skills and empathy. As such, many of the pupils perceived to have developed leadership skills appeared to be viewed by teachers as those who had gained the most from the project experience.

Interestingly, as is illustrated above, many of the skills identified by pupils can be seen to have a relational aspect, pertaining to their connections or interactions with others (e.g. trust, teamwork, communication, empathy and self-confidence) and this reflects the social nature of the group activities that the pupils undertook at the Outward Bound centres. The perceived relevance of acquiring/developing key skills can perhaps also be seen to reflect the literature (PYD, physical education and youth mentoring) on viewing such 'resources' as social and cultural capital. This is discussed in more detail in the following section.

\section{(vi) Discussion}

The data from this research both corroborate and extend existing knowledge on positive youth development through physical activity/sport (Holt, 2008; Hellison et al., 2008). Three issues are of particular importance: the selection of pupils; the 'transfer' of key skills; and the importance of positive social relationships. Each of these issues is discussed in turn, followed by an analysis of their contribution to our understanding of programme design for (sustained) impact.

\section{Selection of pupils}

Belief in the need to match closely individual pupil needs with specific project characteristics or objectives (Findings 1) has been noted elsewhere in the youth physical activity literature and 
has been linked to the importance of providing personalised learning experiences (e.g. DfES, 2004; Sandford et al., 2008a,b). The data from the HSBC/OB project, particularly the pupils showing no change or negative change from their baseline profiles, support this belief. It is apparent that physical activity/sport interventions are no panacea for social problems, nor can they expect to appeal to or influence every individual in the same way (Hartmann \& Wheelock, 2002). Data from the HSBC/OB project (Findings 2) show that those pupils who engaged most with the project activities were those who also became involved in additional activities, where they were presented with opportunities to use and apply their newly acquired/developed skills in different contexts. This issue links closely with the next.

\section{'Transfer' of skills}

Given the acknowledged importance of skill transfer in the PYD literature (e.g. Holt, 2008) it is unsurprising to find that these individuals were the ones perceived to have benefited most from their involvement with the HSBC/OB project. Theokas et al. (2008) point out that transfer of skills is a key factor in PYD programmes using sport/physical activity, commenting that 'the ability to transfer skills learned in sports to other domains is perhaps the most crucial step in achieving maximum outcome from participation in sports' (pp. 72-73). These authors also note that 'what is learned in the athletic venue must be able to be transferred to non-sport settings' (p.78) and they highlight a number of strategies that can potentially aid transfer, such as designing conditions to enhance transfer before the activity commences, providing opportunities for reflection and ensuring follow-up experiences are in place to enhance and reinforce learning.

Although some of these conditions were met within the HSBC/OB project, we have argued elsewhere (Authors, b, c) that the provision of follow-up activities was an area of project design that was underdeveloped. Certainly the data and the wider PYD literature provide 
evidence to suggest that, at the very least, specific planning for skill transfer should be built into project design. Yet, it is also possible to question the validity of the whole notion of 'transfer' in the context of learning. Hager \& Hodkinson (2009) argue that we need to reconsider the strategy of 'using the metaphor of learning transfer for trying to understand what happens when people learn something new and/or move into new and different situations' (p. 620). These authors remind us that it is people who move between contexts (rather than disembodied knowledge or skills) and, drawing upon Bourdieu, they also point out that capital 'is relative to the field within which it is used' (p. 632). Thus, they argue for a more complex understanding of learning as 'becoming within a transitional process of boundary crossing' (p.635). This view seems to take us beyond some of the more mechanistic - and simplistic - approaches to skill learning evident in some of the PYD literature. Certainly the data from this study illustrate the complexities of such transfer, cautioning against naive beliefs in the inherent value of physical activity/sport settings for PYD. .

\section{Positive social relationships}

The data from the HSBC/OB project (see Findings 3) provide clear support for the body of literature that highlights the importance of social and relational processes in physical activity programmes for disaffected youth (e.g. Hellison et al., 2008) and, indeed, for the potential of the PYD approach (Lerner et al., 2008). Several authors have pointed out that caring and supportive adult-youth relationships are an important feature of any effective development context, and should be a central aspect of sport/physical activity programme intended to promote PYD (e.g. Fraser-Thomas et al., 2005). As Petipas et al. (2008) have argued, positive growth in young people is most likely when they 'are surrounded by external assets, including a positive community environment with caring adult mentors' (p.61). It is not just the presence of adult helpers/leaders within PYD programmes that is important, therefore, but the quality of the 
relationships, and the nature of the network developed between adults and young people. This, of course, reinforces the importance of training and supervision for all adult leaders/mentors involved in PYD initiatives. As Côté et al (2008) have argued: 'appropriate training that includes the principles of positive youth development should be provided to all adult leaders in youth sport programs’ (p.42). An important feature of the HSBC/OB project was the level of training provided for mentors and its youth development focus. Mentors found this training to be revealing, suggesting that they were totally unprepared for the realities of the young people they had volunteered to support (Authors, d).

\section{Sustaining positive impact?}

It can be argued that underpinning the findings from this research is the notion of fostering positive personal and social development through the acquisition, over time, of (socially acceptable) skills and traits. Earlier in the paper, it was noted that this concept of developing assets, or resources, was linked strongly to context within the PYD literature. This point is reinforced in the HSBC/OB data. Furthermore, it was argued earlier that that there was a perceptible link to this notion of assets and the concept of social capital, as outlined in the work of theorists such as Bourdieu (1985; 1997). What this seems to suggest is that the skills/assets acquired and developed through a PYD process can be seen to function as valued social (even physical) capital. It could, therefore, be argued that the process of skill transfer affords young people the opportunity to convert this capital into other usable forms (e.g. cultural or economic capital), thereby aiding their progression within relevant social fields (Bourdieu, 1985; Shilling, 1997). On the other hand, as was noted earlier, any simplistic notion of learning 'transfer' should be questioned.

Colley (2003) offers an interesting insight on these issues in her review of mentoring for social inclusion. She argued that the process of aligning young people's resources (skills and 
dispositions) to 'acceptable' social values can be seen, potentially, to increase individuals' social and cultural capital resulting in a form of empowerment. Colley also suggested that such an approach can be viewed as a way of reforming an individual's habitus in line with approved social values, and there are some parallels here with the intended processes of PYD through sport/physical activity. In other words, the process of encouraging the development of prosocial skills through physical activity/sport participation, and then reinforcing them over time via 'transfer' to other contexts, can be better conceptualised as a means of slowly reforming the habitus of disaffected or disengaged young people. This would appear to link closely to the arguments of Hager and Hodkinson (2009) on viewing learning as a process of 'becoming'. They point out, for example, that we need to understand a learner as

'a person whose social and embodied self includes skill, knowledge and understanding. These can be understood as integral parts of the person. Each person has constructed that skill or knowledge as part of themselves. Here, learning is viewed as a relational web, a process of ongoing change’ (p.631).

This argument leads Hager and Hodkinson to conclude that 'people become through learning and learn through becoming' signalling learning as a continuous process that does not 'entail a fixed state of having become’ (p. 633). There are clear links here with Colley’s (2003) notion of reforming the habitus. Taken together, these two theoretical approaches offer much promise for informing the design of future sport/physical activity PYD programmes, and provide a fruitful line of enquiry for further research. Perhaps most importantly, a more complex understanding of learners and learning might help to explain, to programme sponsors, why some of their targets for success are likely to be unrealistic. What the findings of this research illustrate, in some detail, is the complexity of the process of seeking PYD outcomes from physical activity/sport (or indeed any) interventions. Such complexity may be inconvenient in programme design where relatively ‘quick fixes’ seem to be desired. Yet without taking the full 
Running Head: POSITIVE YOUTH DEVELOPMENT THROUGH PHYSICAL ACTIVITY

range of issues into account, it seems likely that most interventions of this nature will continue to be limited in sustained value.

\section{Conclusion}

In our earlier paper (Authors, a), an analysis of the physical activity/sport and PYD literature led to the identification of six key points to be considered in future project design. These were: re-evaluate current practice in the light of evidence; recognise the significance of social relationships; create a sense of community; employ a multi-agency approach; build a structure to ensure sustainability; and incorporate credible monitoring and evaluation. It is suggested that this evaluation of the HSBC/OB project has corroborated some of these points and shed further light on others. For example, it was recognised that relationships with key adults were central to positive impact because attempts were made to involve HSBC staff as 'mentors' to the young people, and to train them for this role. The sponsors also funded evaluation research for the life of the project, and they were keen to use emerging findings to improve the experience for subsequent cohorts of young people.

One of the key lessons to be learnt from this project, however, is about sustaining positive impact on young people beyond their involvement in project activities. To some extent, the HSBC/OB project design did take cognisance of suggestions that project activities should be sustained (e.g. Morris et al., 2003) and there is certainly evidence that those pupils who retained involvement in the project for the longest were more likely to sustain positive impact. Moreover, where schools embraced the project fully by organising additional follow-up activities and linking pupils to compatible activities (such as DoE), the outcomes for pupils appeared to be more positive. What is clear, however, is that in order for more disengaged/disaffected young people to gain the maximum possible from investment in such sport/physical activity interventions, it is important to view the physical activity setting as 
having the potential for positive impact learning, rather than as a panacea for addressing an unrealistic plethora of personal and social issues. Moreover, there could be some advantage in conceptualising learning differently (as a process of becoming) and the changes required and any positive impact desired as 'reforming habitus'. This would, at the very least, signal some caution where sponsors and organisers expect to see impact in any simplistic manner and transfer of skills from one setting to another in unproblematic ways. We would suggest this is an avenue for further research.

Finally, there are lessons to be learnt for evaluators. It is important to acknowledge that the project sponsors were keen to learn from the evaluation, to make changes to the project based on emerging findings and to understand impact. Even so, the challenges posed by the numbers of pupils involved, the range of reasons for selection, the lack of any feasible way of calibrating teachers' descriptions of pupils (for example as 'withdrawn', shy, or disengaged) and the limited time teachers have available to provide impact data on project pupils let alone a comparison group (most refused) made this research daunting. The limitations of the research are many; nonetheless, we would argue that by borrowing Crabbe and colleague’s (2006) notion of 'distance travelled', using individual pupil profiling, and using a range of different methods to view the same issues, we are able to make an evidence-based contribution to the literature in this field.

\section{References}

Authors (a)

Authors (b)

Authors (c)

Authors (d) 
Alderson, P. (2008) Children as researchers: participation rights and research methods, in: P. Christensen \& A. James (Eds) Research with children: Perspectives and practices, Second Edition (276-290) (London, Routledge).

Bailey, R. 2005. Evaluating the relationship between physical education, sport and social inclusion. Educational Review 57, no.1: 71-90.

Bailey, R. (2008) Youth sport and social inclusion. In Positive Youth Development through Sport, ed. N. Holt, 85-96. London: Routledge.

Bailey, R., Armour, K., Kirk, D., Jess, M., Pickup, I., \& Sandford, R. (2009). The educational benefits claimed for physical education and school sport: An academic review. Research Papers in Education, 24(1), 1-27.

Bourdieu, P. (1985). The social space and the genesis of groups. Theory and Society, 14(6), 723-744.

Bourdieu, P. (1997) The forms of capital. In A.H. Halsey, H. Lauder, P. Brown \& A. Stuart Wells (Eds.) Education: Culture, Economy, Society pp. 46-58. Oxford: Oxford University Press.

Charmaz, K. (2000). Grounded theory: Objectivist \& constructionist methods. In N.K Denzin \& Y.S. Lincoln (Eds.), Handbook of qualitative research (2nd Edition) (pp. 509-536). London: Sage.

Colley, H. (2003). Mentoring for social inclusion: A critical approach to nurturing mentor relationships. London: Routledge Falmer.

Crabbe, T. et al., (2006). Knowing the score, Positive Futures case study research: final report. London: Home Office.

Damon, W. (2004) What is positive youth development? Annals of the American Academy, 59, 13-24. 
Running Head: POSITIVE YOUTH DEVELOPMENT THROUGH PHYSICAL ACTIVITY

Davies, B. 2005. Threatening youth revisited: youth policies under New Labour. The encyclopaedia of informal education. http://www.infed.org/archives/bernard_davies/revisiting_threatening_youth.html.

DCMS (2010) Plans for the Legacy from the 2012 Olympic and Paralympic Games.

DfES (2004) Five year strategy for children and learners (London: DfES).

DfES (2005) Learning Behaviour: The report of the practitioner's group on school, behaviour and discipline. Available online at: http://www.dfes.gov.uk/behaviourandattendance/about/learning_behaviour.cfm (accessed 20 October 2007).

Donnelly, P., \& Coakley, J. 2002. The role of recreation in promoting social inclusion. Toronto: Laidlaw Foundation.

European Commission (2007) White Paper on Sport. Available online at: http://ec.europa.eu/sport/white-paper/index_en.htm\#wp (accessed 15 June 2011).

Flutter, J. \& Ruddock, J. (2004) Consulting pupils: what's in it for schools?. London: Routledge Falmer.

Fraser-Thomas, J.L., Côté, J. \& Deakin, J. 2005. Youth sport programs: an avenue to foster positive youth development. Physical Education and Sport Pedagogy 10, no.1: 19-40.

Fulbright-Anderson, K., Kubisch, A.C. \& Connell, J.P. (2002) New Approaches to Evaluating Community Initiatives: Theory, Measurement and Analysis, vol 2. Washington DC: The Aspen Institute.

Glaser, B. G., \& Strauss, A.L. (1967). The discovery of grounded theory: Strategies for qualitative research. New York: Aldine de Gruyter.

Goldson, B. \& Muncie, J. (2006) Youth crime and justice. London: Sage Publications.

Granger, R.C. (1998). Establishing causality in comprehensive community initiatives, in K. Fulbright-Anderson, A.C. Kubisch and J.P. Connell (eds) New Approaches to 
Running Head: POSITIVE YOUTH DEVELOPMENT THROUGH PHYSICAL ACTIVITY

Evaluating Community Initiatives: Theory, Measurement and Analysis, vol 2 pp. 22146 (Washington DC, The Aspen Institute).

Granger, R.C. (2002). Creating the conditions linked to positive youth development. New Directions for Youth Development, 95, 149-164.

Hager, P. \& Hodkinson, P. (2009). Moving beyond the metaphor of transfer of learning. British Educational Research Journal, 35(4), 619-638.

Halsey, K., Murfield, J., Harland, J.L. \& Lord, P. (2006) The voice of young people: an engine for improvement? scoping the evidence (London: CfBT Education Trust).

Harper, D. (2002) Talking about pictures: A case for photo elicitation. Visual Studies, 17(1), $13-26$.

Harry, B., Sturges, K.M., \& Klingner, J.K. (2005). Mapping the process: An exemplar of process and challenge in grounded theory analysis. Educational Researcher, 34(2), 3-13.

Hartmann, D., \& Wheelock, D. (2002) Sport as prevention? Minneapolis’ experiment with latenight basketball. The CURA Reporter [Center for Urban and Regional Affairs, University of Minnesota], 32(3), 13-17.

Hellison, D. 1995. Teaching responsibility through physical activity. Champaign, IL: Human Kinetics.

Hellison, D., Martinek, T. \& Walsh, D. (2008). Sport and responsible leadership among youth. In N.L.Holt (Ed.), Positive youth development through sport (pp.49-60). London: Routledge.

Holt, N. (Ed) 2008. Positive youth development through sport. London: Routledge.

Holt, N. L., Tink, L. N., Mandigo, J. L. \& Fox, K. R. (2008). Do youth learn life skills through their involvement in high school sport? Canadian Journal of Education, 31(2), 281-304.

Hughes, G. \& Follett, M. (2006) Community safety, youth and the 'anti-social'. In B. Goldson \& J. Muncie (eds.) Youth crime and justice (pp. 157-171). London: Sage Publications. 
Jones, K. R. (2005). Positive youth development. Cooperative Extension Service. Lexington, KY: University of Kentucky.

Kellogg Foundation (2004). Using logic models to bring together planning, evaluation and action: Logic model development guide. Michigan: W.K. Kellogg Foundation.

Kendall, S. \& Kinder, K. (2005) Reclaiming those disengaged from education and learning: a European perspective (Slough, NFER).

Lerner, R.M., Almerigi, J.B., Theokas, C. \& Lerner, J.V. (2005a) Positive youth development: a view of the issues. The Journal of Adolescence, 25(1), 10-16.

Lerner, R.M., Lerner, J.V., Almerigi, J.B. Theokas, C., Phelps, E., Naudeau, S., et al. (2005b) Positive youth development, participation in community youth development programs, and community contributions of fifth grade adolescents: Findings from the first wave of the 4-H study of Positive Youth Development. Journal of Early Adolescence, 25: 17-71.

Lerner, R.M., Lerner, J.V., Phelps, E. et al. (2008) The positive development of youth: Report of the findings from the first four years of the 4-H study of positive youth development. Tufts University: Institute for Applied Research in Youth Development.

MacCallum, J. \& Beltman, S. 2002. Role Models for Young People: What makes an effective role model program? A report to the National Youth Affairs Research Scheme. Hobart: Australian Clearinghouse for Youth Studies

Maxwell, J.A. (2004) Causal explanation, qualitative research, and scientific inquiry in education, Educational Researcher, 33(2), 3-11.

Morris, L., Sallybanks, J., Willis, K., \& Makkai, T. 2003. Trends and issues in crime and criminal justice. Australian Institute of Criminology.

http://www.aic.gov.au/publications/tandi/tandi249.html.

Newburn, T., Shiner, M., Groben, S. \& Young, T. (2005). Dealing with disaffection: young people mentoring and social inclusion. London: Willan Publishing. 
Nichols, G. (2007). Sport and crime reduction: the role of sports in tackling youth crime (London, Routledge).

Oliver, K. L. \& Lalik, R. (2001) The body as curriculum: Learning with adolescent girls, Journal of Curriculum Studies, 33(3), 303-333.

Parker, M. \& Stiehl, J (2005). Personal and Social Responsibility. In Tannehill, D. \& Lund, J. (Eds.). Standards based curriculum development. Boston, MA: Jones and Barlett.

Petitpas, A. Cornelius, A. \& Van Raalte, J. (2008) Youth development through sport. In, N.Holt (Ed.) Positive youth development and sport (pp.61-70). London: Routledge.

Putnam, R.D. (2000) Bowling alone. New York: Touchstone.

Sandford, R., Armour, K. \& Duncombe, R. 2008. Physical activity and personal/social development for disaffected youth in the uk: in search of evidence. In Positive Youth Development through Sport, ed. N. Holt, 97-109. London: Routledge.

Sandford, R.A., Duncombe, R. \& Armour, K.M. (2008) The role of physical activity/sport in tackling youth disaffection and anti-social behaviour, Educational Review, 60(4) pp.419-435.

Shilling, C. (1993). The Body and Social Theory. London: Sage Publications.

Smink, J. (2000). Foreword. In R. Klein, Defying disaffection: How schools are winning the hearts and minds of reluctant students. Stoke on Trent, UK: Trentham Books.

Spencer, L., Ritchie, J., Lewis, J., \& Dillon, L. (2003). Quality in qualitative evaluation: A framework for assessing research evidence. London: National Centre for Social Research.

Strauss, A. L., \& Corbin, J. (1998). Basics of qualitative research: Techniques and procedures for developing grounded theory (2nd edition). Thousand Oaks, CA: Sage Publications.

Theodoulides, A. \& Armour, K.M. (2001) Personal, social and moral development through team games: some critical questions. European Physical Education Review, 7(1), 5-23. 
Theokas, C., Danish, S., Hodge, K., Heke, I. \& Forneris, T. (2008) Enhancing life skills through sport for children and youth. In, N.Holt (Ed.) Positive youth development and sport (pp.71-81). London: Routledge.

Weiss, C. H. (1995). Nothing as practical as good theory: exploring theory-based evaluation for comprehensive community initiatives for children and families. In J. Connell, A. Kubisch, L. Schorr \& C. Weiss (Eds.), New approaches to evaluating community initiatives: concepts, methods, and contexts (pp. 65-92).

Whitlock, J.L. (2004) Understanding Youth Development Principles and Practices. (Research Brief). Ithaca, NY: ACT for Youth Center of Excellence, Cornell University. Family Life Development Center

Winter, N. (2003). Social capital, civic engagement and positive youth development outcomes. Washington, DC: Policy Studies Associates.

\section{Website References}

DCMS website:

http://www.culture.gov.uk/what_we_do/2012_olympic_games_and_paralympic_games/3426.as $\underline{\mathrm{px}}$

Tables

\begin{tabular}{|c|c|c|c|c|c|c|c|c|c|c|c|c|}
\hline \multirow[t]{2}{*}{$\begin{array}{c}\text { ALL } \\
\text { SCHOOLS } \\
\text { (Cohorts 1-3) }\end{array}$} & \multicolumn{4}{|c|}{$\begin{array}{c}\text { Positive Change from } \\
\text { Baseline } \\
\text { (\%) }\end{array}$} & \multicolumn{4}{|c|}{$\begin{array}{l}\text { No Change from Baseline } \\
\text { (\%) }\end{array}$} & \multicolumn{4}{|c|}{$\begin{array}{c}\text { Negative Change from } \\
\text { Baseline } \\
(\%)\end{array}$} \\
\hline & $\begin{array}{c}6 \\
\text { mth }\end{array}$ & $\begin{array}{r}12 \\
\text { mth }\end{array}$ & $\begin{array}{c}24 \\
\text { mth }\end{array}$ & $\begin{array}{r}36 \\
\text { mth }\end{array}$ & $\begin{array}{c}6 \\
\text { mth }\end{array}$ & $\begin{array}{r}12 \\
\text { mth }\end{array}$ & $\begin{array}{c}24 \\
\text { mth }\end{array}$ & $\begin{array}{c}36 \\
\text { mth }\end{array}$ & $\begin{array}{c}6 \\
\text { mth }\end{array}$ & $\begin{array}{c}12 \\
\text { mth }\end{array}$ & $\begin{array}{r}24 \\
\text { mth }\end{array}$ & $\begin{array}{r}36 \\
\text { mth }\end{array}$ \\
\hline $\begin{array}{l}\text { Project Group } \\
(n=440)\end{array}$ & 59.7 & 59.6 & 53.2 & 53.2 & 28.3 & 27.4 & 26.5 & 37.5 & 12.0 & 13.0 & 16.7 & 9.3 \\
\hline $\begin{array}{l}\text { Comparison } \\
\text { Group }(n=120)\end{array}$ & 35.4 & 42.0 & 40.7 & 43.5 & 41.5 & 36.4 & 31.5 & 43.7 & 23.2 & 21.6 & 27.8 & 12.8 \\
\hline
\end{tabular}


Running Head: POSITIVE YOUTH DEVELOPMENT THROUGH PHYSICAL ACTIVITY

3

\begin{tabular}{|l|c|c|c|c|c|c|c|c|c|c|c|c|}
\hline $\begin{array}{l}\text { Weekend } \\
\text { Event (n=138) }\end{array}$ & 79.2 & 71.5 & 70.2 & 63.0 & 15.0 & 21.3 & 20.2 & 32.8 & 5.8 & 7.2 & 9.6 & 4.2 \\
\hline $\begin{array}{l}\text { Classic Course } \\
(\mathbf{n}=\mathbf{2 9})\end{array}$ & 81.1 & 82.5 & 78.9 & 75.0 & 18.9 & 15.0 & 17.8 & 25.0 & 0 & 2.5 & 3.34 & 0 \\
\hline
\end{tabular}

4 Table 1: Table showing the percentage of pupils demonstrating a particular direction of

5 change (from baseline) over time following commencement of the HSBC/OB project

6 
Running Head: POSITIVE YOUTH DEVELOPMENT THROUGH PHYSICAL ACTIVITY

\begin{tabular}{|c|c|c|c|c|c|}
\hline \multirow[t]{2}{*}{ Name } & \multirow[t]{2}{*}{ Profile } & \multicolumn{4}{|c|}{ Progress Report } \\
\hline & & 6 months & 12 months & 24 months & 36 months \\
\hline $\begin{array}{l}\text { Andrew } \\
\text { (School A) }\end{array}$ & $\begin{array}{l}\text { Totally } \\
\text { disengaged from } \\
\text { school. Always in } \\
\text { trouble with } \\
\text { teachers, never } \\
\text { does work. } \\
\end{array}$ & $\begin{array}{l}\text { No change if anything he is } \\
\text { getting worse as the weeks } \\
\text { go on. (NC) }\end{array}$ & $\begin{array}{l}\text { No change! He's got even } \\
\text { more silly. }(N)\end{array}$ & $\begin{array}{l}\text { Has lost it all! Behaviour is the worst in } \\
\text { school. He's withdrawn from all lessons, } \\
\text { not allowed to have same breaks as other } \\
\text { kids. Suspended on a few occasions. }(N)\end{array}$ & $\begin{array}{l}\text { Has gone off the wall completely. } \\
\text { Excluded from school every month. (N) }\end{array}$ \\
\hline $\begin{array}{l}\text { James } \\
\text { (School B) }\end{array}$ & $\begin{array}{l}\text { Quiet, well- } \\
\text { behaved student, } \\
\text { who despite being } \\
\text { reasonably quiet, } \\
\text { interacts well } \\
\text { with his peers. }\end{array}$ & $\begin{array}{l}\text { No improvement. Seems to } \\
\text { be demotivated and has a } \\
\text { negative attitude towards } \\
\text { school related activities. }(N)\end{array}$ & No feedback given & $\begin{array}{l}\text { Has matured considerably during the } \\
\text { year - always works hard and attendance } \\
\text { excellent. }(P)\end{array}$ & $\begin{array}{l}\text { Very sensible and hardworking pupil, } \\
\text { who is doing very well in school. }(P)\end{array}$ \\
\hline $\begin{array}{l}\text { Hayley } \\
\text { (School C) }\end{array}$ & $\begin{array}{l}\text { Selected for } \\
\text { outstanding effort } \\
\text { in school, lacks } \\
\text { confidence. }\end{array}$ & $\begin{array}{l}\text { Not as quiet as before the } \\
\text { residential. She has found a } \\
\text { voice and is no longer Amy's } \\
\text { 'sidekick' More likely to stop } \\
\text { and talk to staff of her own } \\
\text { accord }(P)\end{array}$ & $\begin{array}{l}\text { She is on the edge of the } \\
\text { group. She doesn't join in } \\
\text { much with group activities. } \\
\text { No problems in school } \\
\text { though. She is a polite and } \\
\text { pleasant young woman (NC) }\end{array}$ & $\begin{array}{l}\text { Is making general progress in role of } \\
\text { prefect and has been praised. }(P)\end{array}$ & $\begin{array}{l}\text { Was fairly 'off track' for most of Year } \\
\text { 11. An intelligent girl who did not } \\
\text { obtain her potential. }(N)\end{array}$ \\
\hline $\begin{array}{l}\text { William } \\
\text { (School D) }\end{array}$ & $\begin{array}{l}\text { SEN Level 5. Shy } \\
\text { but determined. }\end{array}$ & $\begin{array}{l}\text { He completed the experience } \\
\text { well and made new friends. } \\
(P)\end{array}$ & $\begin{array}{l}\text { A changed man! In my } \\
\text { opinion one of the greatest } \\
\text { impacts. His confidence and } \\
\text { communication are vastly } \\
\text { improved. }(P)\end{array}$ & $\begin{array}{l}\text { Probably the greatest success story. } \\
\text { Previously shy, underachieving and on } \\
\text { the receiving end of some bullying. Now } \\
\text { confident, achieving above expectations } \\
\text { and developing some very good social } \\
\text { skills. Also in regular contact with a } \\
\text { business mentor. }(P)\end{array}$ & $\begin{array}{l}\text { Outstanding improvement in quality of } \\
\text { work and self-belief to improve } \\
\text { achievement. }(P)\end{array}$ \\
\hline $\begin{array}{l}\text { Jenny } \\
\text { (School E) }\end{array}$ & $\begin{array}{l}\text { A well motivated } \\
\text { pupil and } \\
\text { potentially a good } \\
\text { leader. From low } \\
\text { socioeconomic } \\
\text { group and lacks } \\
\text { opportunities. } \\
\end{array}$ & $\begin{array}{l}\text { No significant change. I feel } \\
\text { we may see a change over a } \\
\text { longer period of time. (NC) }\end{array}$ & $\begin{array}{l}\text { Jenny is making good } \\
\text { progress. }(P)\end{array}$ & Still progressing well. $(P)$ & $\begin{array}{l}\text { Very positive student, has grown in } \\
\text { maturity and confidence. }(P)\end{array}$ \\
\hline
\end{tabular}

7 Table 2: Table illustrating the varied paths to progress for some participants in the HSBC/OB project 
Table 3

\begin{tabular}{|l|c|c|c|c|}
\hline \multirow{2}{*}{} & \multicolumn{5}{|c|}{ Approx. no. of pupils who went on to take part in other developmental } \\
& Cohort 1 & Cohort 2 & Cohort 3 & Cohort 4 \\
\hline School A & $10(34.5 \%)$ & - & - & - \\
\hline School C & $11(39.3 \%)$ & $11(35.5 \%)$ & - & - \\
\hline School D & $12(41 \%)$ & $15(50 \%)$ & $12(40 \%)$ & $15(50 \%)$ \\
\hline School E & $4(13.3 \%)$ & $3(9.7 \%)$ & $2(6.7 \%)$ & $4(13.3 \%)$ \\
\hline
\end{tabular}

Table showing the number of pupils (and percentage of the school cohort) who progressed

to further developmental activities following their participation in the HSBC/OB project.

Table 4.

\begin{tabular}{|l|c|c|c|c|}
\hline \multirow{2}{*}{} & \multicolumn{4}{|c|}{ Approx. no. of pupils who went on to take roles of responsibility within } \\
& \multicolumn{2}{|c|}{ school } \\
\cline { 2 - 5 } & Cohort 1 & Cohort 2 & Cohort 3 & Cohort 4 \\
\hline School C & $9(32.1 \%)$ & $7(22.6 \%)$ & - & - \\
\hline School D & $14(48 \%)$ & $16(53 \%)$ & $12(40 \%)$ & $16(53 \%)$ \\
\hline School E & $2(6.6 \%)$ & $1(3.2 \%)$ & $4(13.3 \%)$ & $5(16.7 \%)$ \\
\hline
\end{tabular}

14 Table indicating the number of pupils (and percentage of the school cohort) who went on take on roles of responsibility within the school following their participation in the

\section{Table 5}

\begin{tabular}{|l|l|}
\hline Skill /Attribute & Illustration from Data \\
\hline SELF-CONFIDENCE & $\begin{array}{l}\text { "I learnt that you shouldn't be afraid of anything, you should be confident and } \\
\text { you will be able to overcome it" } \\
\text { "I have learnt that I am braver, more confident and more courageous than I } \\
\text { have ever thought in my life” }\end{array}$ \\
\hline $\begin{array}{l}\text { COMMUNICATION } \\
\text { SKILLS }\end{array}$ & $\begin{array}{l}\text { "Before I wouldn't say much, I was too shy, but now I say more in class" } \\
\text { communication you get nowhere" }\end{array}$ \\
\hline $\begin{array}{l}\text { TEAMWORK } \\
\text { SKILLS }\end{array}$ & $\begin{array}{l}\text { "I learnt that you have to work as a team and you can't be independent all the } \\
\text { time" }\end{array}$ \\
\hline
\end{tabular}




\begin{tabular}{|c|c|}
\hline & $\begin{array}{l}\text { "I've learnt that not everyone is capable of doing what you can do. You have to } \\
\text { help each other in order to reach your goal" }\end{array}$ \\
\hline TRUST & $\begin{array}{l}\text { "The most important thing I learnt was trust and safety. I almost injured myself } \\
\text { when I didn't listen to these instruction" } \\
\text { "I learnt that you should trust your friends, because when you need help your } \\
\text { friends give you the confidence to make you do something” }\end{array}$ \\
\hline $\begin{array}{l}\text { WILLINGNESS TO } \\
\text { TRY }\end{array}$ & $\begin{array}{l}\text { "It's really changes the way you think about things, because before you just } \\
\text { say you're not going to do it, but then as you put your willpower and your mind } \\
\text { to it, then you do it, and you feel much better about yourself when you've done } \\
\text { it, because you know you've achieved it" } \\
\text { "Sometimes if you think you've got to do something new you don't want to try } \\
\text { it, but you've tried everything (at the Outward Bound centre). So always try } \\
\text { something new even if you are not sure you are going to like it" }\end{array}$ \\
\hline $\begin{array}{l}\text { EMPATHY / } \\
\text { SOCIAL } \\
\text { RESPONSIBLTY }\end{array}$ & $\begin{array}{l}\text { "I learnt how to encourage other people because when people were like } \\
\text { (saying) they can't go no further... like Alice she used to be in my class, I was } \\
\text { encouraging her to come up the hill and I was helping her and holding her up } \\
\text { making her more confident" } \\
\text { "The most important thing I have learnt is caring for one another" }\end{array}$ \\
\hline $\begin{array}{l}\text { OVERCOMING } \\
\text { FEARS / FACING } \\
\text { CHALLENGES }\end{array}$ & $\begin{array}{l}\text { 'I learnt you push yourself to the boundaries, further than you thought you } \\
\text { could' } \\
\text { 'Rock climbing was really good, I faced my fears and didn't give up, I carried } \\
\text { on' }\end{array}$ \\
\hline PERSEVERANCE & $\begin{array}{l}\text { "I have learnt DO NOT QUIT" } \\
\text { "I think I learnt something today - not to give up and however many times I } \\
\text { fall I will climb again and I'll reach the top" }\end{array}$ \\
\hline
\end{tabular}

Table illustrating a sample of the pupil data collated in relation to the issue of skills 